\title{
Chemical and Physicochemical Composition of Watermelon Seed Oil (Citrullus lanatus L.) and Investigation of the Antioxidant Activity
}

\section{Chemical constituents and Antioxidant Activity of Citrullus lanatus L. Seed Oil}

\author{
[Oloyede, G. K. ${ }^{*}$ and Aderibigbe S. A. ${ }^{2}$ ]
}

\begin{abstract}
Citrullus lanatus L. (Cucurbitaceae) known as Water melon is an edible fruit in many countries especially Nigeria. Chemical composition, phytochemical, physicochemical and antioxidant properties of the dried seeds of $C$. lanatus were determined to understand its potential health benefits since oil extract from a number of fruits, nuts and seeds are used in cooking, soap making and as ingredient in confectioneries of baked or fried foods. Dried and pulverized Watermelon seeds were extracted using hexane at $60-70^{\circ} \mathrm{C}$. Standard methods were used to determine phytochemical and physicochemical parameters. The chemical composition of the oil was determined using Gas-Chromatography - Mass Spectrometry (GC-MS) while antioxidant activity was determined using 2, 2diphenylpicrylhydrazyl radical (DPPH) and reducing power methods. Results showed that the light yellow oil with an average yield of $41.32 \%$ showed the presence of terpenoids, phenolics, glycosides, and carbohydrate. Physicochemical parameters such as acid value 2.03 , saponification value 183.13 , iodine value 121.51, specific gravity 0.85 , viscosity 2.48 , refractive index 1.47 and power of hydrogen 6.20 were reported. Oleic acid methyl ester $(62.38 \%)$ was the most abundant compound detected in the seed oil. The seed oil showed moderate activity when compared with ascorbic acid in the antioxidant screening when DPPH and reducing power methods were used. This present study has greatly justified the use of watermelon as an edible medicinal fruit.
\end{abstract}

Keywords- Methyl 9-cis, 11 -trans-octadecadienoate, methyl palmitate, seed oil, 2,2-diphenyl-1-picrylhydrazyl, Citrullus lanatus

Ganiyat K. Oloyede (PhD)

Department of Chemistry, University of Ibadan,

Nigeria

$+2348035622238$

Sodeeq A. Aderibigbe

Department of Chemistry, National Open University of Nigeria, Nigeria

\section{Introduction}

Fruits are the fleshy seed-associated structures of a plant that is sweet or sour, and edible in the raw state, for example oranges, apples and banana, but in botanical usage, "fruit" includes many structures that are not commonly called "fruits", such as tomatoes, bean pods, wheat grains and corn kernels (Desai and Salunkhe, 1991; Munisse, et al., 2011). Fruits and vegetables are of particular interest for their content in phytochemicals, antioxidants, vitamins, minerals and dietary fiber. All these substances are reported to lower the risk of development of health problems such as certain types of cancer, cardio vascular diseases, type 2 diabetes, obesity and constipation. Low intake of fruits can lead to increased risk of lung cancer and nutritional deficiencies (El-Adawy and Taha 2001; Sun, 2002).

Watermelon (Citrullus lanatus L.) of the family Cucurbitaceae is an important horticultural crop, mostly grown for its sweet and juicy fruit in warm climates all over the world. It is a vine-like flowering plant. It is referred as a pepo by botanists, which is a berry having a thick rind (exocarp) and fleshy center (mesocarp and endocarp). When used fresh or processed into juice, it generates much waste in the form of rind and seeds (Aranceta, 2004; Parry, et al., 2005). The crops are primarily harvested for juice and juice concentrate. Although the seeds are considered waste, they have been shown to be highly nutritive and contain large amounts of proteins, vitamin A, C, E and many beneficial minerals (Rossell, 1991; Taiwo, et al., 2008). Melons have their origin in Africa and Southwest Asia, but later started appearing in Europe at the end of the Roman Empire. Melons are nourishing food as its seeds are used to treat tuberculosis because of the high levels of potassium and are considered diuretics due to their high water content which is as high as $92 \%$ of the total weight. The presence of lycopene, an antioxidant found in some fruits and vegetables gives it the ability to lower the risk of cancer (Ensminger and Ensminger, 1986; Tarazona-Díaz et al., 2013; Gul et al., 2014).

Recently, more attention has been paid to the utilization of byproducts and wastes, as well as underutilized agricultural products. Such utilization will contribute to maximizing available resources and can also result in the production of new foods (Oyedeji and Oderinde, 2006). Watermelons are one of the major underutilized fruits grown in warmer parts of the world. Farmers in Namibia grow three types of watermelons: dessert, seed and the cooking types. Watermelon is basically classified into the seeded (diploid) and the seedless (triploid) watermelon (Lawrence, 1985). The crop is a natural and rich source of phytochemical compounds which are believed to be beneficial for human health and well-being (AbuReidah et al., 2013). The seeds have a high nutritive value and are a potential source of unsaturated fat, vitamins, antioxidants, minerals 
and proteins. Other benefits of watermelon include promoting a healthy complexion and hair, increase energy, and lower weight. Choline, found in watermelon is a very important and versatile nutrient; it aids sleep, muscle movement, learning, and memory. It maintains the structure of cellular membranes, aids in the transmission of nerve impulses, assists in the absorption of fat, and reduces chronic inflammation. L-citrulline present in watermelon has been reported to be responsible for muscle soreness reduction and improve recovery time following exercise in athletes (Pari and Umamaheswari, 2000; Rahman, et al., 2013; Tarazona-Díaz, et al. 2013). The seed oil is light, pale yellow in colour, very stable with nutty aroma and is used as carrier oil for essential oil during aromatherapy massage. It is also used as emollient, antioxidant, antiaging, detoxifying agent, anti-inflammatory, antihelminthic, and diuretic (El-Adawy and Taha, 2001; Erhirhie and Ekene, 2013). The oil has been used for cooking by native people of Kalahari Desert, although it is not used for cooking in most places in recent times (ElAdawy and Taha, 2001; Leland, et al., 2006; Munisse, et al., 2011). Little is documented about watermelon and its seeds in Africa, but the indications are that it has versatile uses. Therefore, this study seeks to investigate the phytochemical, physicochemical, chemical composition and antioxidant properties of the extracted watermelon (C. lanatus) seed oil from Nigerian soil. Investigation of the free radical scavenging activity is relevant since free radical and UV radiation induced damage are major causes of accelerated aging and many other diseases. Free radicals are neutral, short lived, unstable and highly reactive chemical species associated with odd or unpaired electron which is capable of attacking the healthy cells of the body, causing them to lose their structure and function. Antioxidants however are capable of stabilizing or deactivating free radicals before they attack cells. Antioxidant is a substance that can efficiently reduce a pro-oxidant with concomitant formation of products having no or low toxicity (Halliwell et al., 1995; Boligon et al., 2014)

\section{Materials and Methods}

\section{Materials Collection and Preparation of Sample}

Samples of watermelon seed (Citrullus lanatus L.) were purchased from Bodija market in Akinyele Local Government Area of Oyo State, Ibadan, Nigeria in June 2016 and identified by a Taxonomist. The melon seeds were air-dried for two weeks, ground and kept in a desiccator till when needed.

Reagents: Hexane, methanol, hydrogen peroxide (BDH chemical), 2,2-diphenyl-1-picrylhydrazyl, potassium ferricyanide, ferric chloride and trichloroacetic acid (Sigma-Aldrich). Ascorbic was used as antioxidant reference standard.

\section{Equipment}

The following apparatus and equipment were used: Buchi Rotary Evaporator fitted with Vacuum pump V-700 and B-490 heating bath was used to concentrate samples. Oven (Carbolite), Ultravioletvisible (UV-visible) spectrophotometer (Unico1200 \& Perkin Elmer lambda 25 model, UK), and Gas Chromatography-mass spectrophotometer (GC-MS) (Gas chromatograph/GC-MS (HP 6890, UK), heating mantle, electronic weighing balance (OHAUS), desiccators, syringes, sample bottles, round bottom flask.

\section{Methods}

\section{Extraction of Seed Oil}

The ground melon seeds (Citrullus lanatus L.) sample (230 g) was transferred into a 10 Litre capacity round bottom flask and $680 \mathrm{ml}$ of pure n-hexane was added, stirred every two hours with a glass rod and allowed to stay for 72 hours. The mixture was collected using muslin bag. This process was repeated by adding another $680 \mathrm{ml}$ of pure n-hexane to the shaft. The combined filtrate was filtered using Whatman filter paper $(1 \mathrm{~mm})$. The filtrate was concentrated with the aid of rotary evaporator set at $35^{\circ} \mathrm{C}$ and the concentrate was transferred into a vacuum oven set at $35^{\circ} \mathrm{C}$ and $700 \mathrm{mmHg}$ pressure. Phytochemical screening was carried out on watermelon seed oil according to the methods of Kokate (1993) and Chitravadivu et al., (2009). Proximate analysis of refractive index, free fatty acid, iodine, saponification, peroxide and acid values were determined for the sample in triplicate in accordance with the Association of Official Analytical Chemist (AOAC) procedures (Pritchard and Rossell, 1991).

\section{Analysis of the Seed Oil}

Gas Chromatography: The seed oil was analysed using an HP 6890 Gas Chromatograph powered with ChemStation Rev. A09.01 [1206] Software at the following specifications: split injection temperature, split ratio: (20:1), with hydrogen as carrier gas. Flow rate: 1.0 $\mathrm{mL} / \mathrm{min}$, inlet temperature: $150^{\circ} \mathrm{C}$, column type: HP $5 \mathrm{MS}$, column dimensions: $30 \mathrm{~m} \times 0.25 \mathrm{~mm} \times 0.25 \mu \mathrm{m}$, oven program: initial at $40^{\circ} \mathrm{C}$, ramped at $5^{\circ} \mathrm{C} / \mathrm{min}$ to $200^{\circ} \mathrm{C}$, and run at $220^{\circ} \mathrm{C}$ for 5 minutes (David et al., 2011; Oloyede and Egbewole, 2014).

Gas Chromatography-Mass Spectrometry: GC oven temperature and conditions were as described above using HP 6890 powered with ChemStation Rev. A09.01 [1206] Software. Mass spectra were recorded at $70 \mathrm{eV}$ (Marriot et al., 2001; Oloyede et al., 2012).

Identification of Components: Relative percentage compositions of constituents were obtained from electronic integration measurement using a Flame Ionization Detector (FID) set at a temperature of $300^{\circ} \mathrm{C}$ while individual components of the oil were identified on the basis of their retention indices determined with reference to a homologous series of n-alkanes and by comparison of their mass spectra fragmentation pattern (NIST0.8 L database/chem. Station system) with data previously reported in literature (Mclafferty and Stauffer, 1989; Gohlke et al., 1993; Adams, 2007; Diomande, 2012). The peak numbers and relative percentages of the characterized components are given in Table 1.

\section{Determination of Antioxidant Activity DPPH Method}

The ability to scavenge radical was determined using the 2,2diphenyl-1-picrylhydrazyl (DPPH) radical method. A $3.94 \mathrm{mg}$ of DPPH radical was dissolved in $100 \mathrm{~mL}$ of methanol to give a $100 \mu \mathrm{M}$ solution. The sample extract $(0.2 \mathrm{~mL})$ from stock solution of $1 \mathrm{~g} / \mathrm{L}$ was diluted with methanol and $2 \mathrm{~mL}$ of DPPH solution $(0.5 \mathrm{mM})$ was added. The decrease in absorption of DPPH at $517 \mathrm{~nm}$ was measured in UV spectrophotometer after 30 minutes of incubation for the various concentrations $(100-1000 \mu \mathrm{g} / \mathrm{mL})$. Analysis was carried out in triplicates and the average results were recorded. The same experiment was carried out on ascorbic acid used as standard. Percentage inhibition was also calculated (Onocha et al., 2011; Oloyede et al., 2012; NurAlam, et al., 2013). 


\section{Reducing Power Method (RP)}

This method is based on the principle that increase in the absorbance of the reaction mixtures indicates an increase in the antioxidant activity. In this method, antioxidant compound forms a colour complex with potassium ferricyanide, trichloro acetic acid and ferric chloride, which is measured at $700 \mathrm{~nm}$ in a UV spectrophotometer. Increase in absorbance of the reaction mixture indicates the reducing power of the samples (Jayaprakash et al., 2001). In the method described by Oyaizu (1986), $2.5 \mathrm{~mL}$ of $0.2 \mathrm{M}$ phosphate buffer $(\mathrm{pH}$ 6.6) and $2.5 \mathrm{~mL}$ of $\mathrm{K}_{3} \mathrm{Fe}(\mathrm{CN})_{6}(1 \% \mathrm{w} / \mathrm{v})$ are added to $1.0 \mathrm{~mL}$ of sample dissolved in distilled water. The resulting mixture is incubated at $50^{\circ} \mathrm{C}$ for $20 \mathrm{~min}$, followed by the addition of $2.5 \mathrm{~mL}$ of trichloro acetic acid $(10 \% \mathrm{w} / \mathrm{v})$. The mixture is centrifuged at 3000 rpm for $10 \mathrm{~min}$ to collect the upper layer of the solution $(2.5 \mathrm{~mL})$, mixed with distilled water $(2.5 \mathrm{~mL})$ and $0.5 \mathrm{~mL}$ of $\mathrm{FeCl}_{3}(0.1 \%$, w/v). The absorbance was measured at $700 \mathrm{~nm}$ against blank sample and recorded.

\section{Results and Discussion}

The extracted oil with an average yield of $41.32 \pm 0.5$ per 100 gm $(41.32 \% \mathrm{w} / \mathrm{w})$ was light yellow in colour. This quantity of extract is considerable and the value is commensurate with reported values for some other similar oil seeds contents such as Cucumismelo (44.85\%) and pumpkin seed oil (41.59\%) (Tilak, et al., 2006; Ziyada and Elhussien, 2008). Phytochemical screening revealed the presence of phenolics, terpenoids, carbohydrate and glycosides while flavonoids, saponin, tannins, reducing sugar and alkaloid were absent. Results of the physicochemical parameters determined are shown in Table 1.

Table 1: Average values of physicochemical analysis of Watermelon seed oil

\begin{tabular}{|l|l|l|}
\hline S/N & Property & Value \\
\hline 1 & Acid Value & 2.03 \\
\hline 2 & Saponification value & 183.13 \\
\hline 3 & Iodine value & 121.51 \\
\hline 5 & Specific gravity & 0.85 \\
\hline 6 & Viscosity & 2.48 \\
\hline 7 & Refractive index & 1.47 \\
\hline & $\begin{array}{l}\text { Power of Hydrogen } \\
\text { Free fatty acid content }\end{array}$ & $6.20 \%$ \\
\hline
\end{tabular}

The values obtained for measure of un-saturation of oil (iodine value), percentage of volatile oils (free fatty acids content), measure of the average carbon chain length (saponification value) and specific gravity (Table 1) obtained in this analysis were in conformity with was previously reported by Duduyemi et al.(2013) which were $121.51,6.40 \%, 183.13$ and 0.85 respectively. Baboli and Kordi
(2010) also reported that watermelon seeds oil from Iran produced yields of $50 \%(\mathrm{w} / \mathrm{w})$ oil and the refractive index, saponification and iodine value were 1.4712 (at $25^{\circ} \mathrm{C}$ ), $200 \mathrm{mg} \mathrm{KOH} / \mathrm{g}$ and $156 \mathrm{~g}$ $\mathrm{I} / 100 \mathrm{~g}$, respectively. The acid and peroxide values were $2.4 \mathrm{mg}$ $\mathrm{KOH} / \mathrm{g}$ and 3.24 mequiv/kg, respectively. The values obtained were at par with the result obtained from this present study. The specific gravity of 0.85 for watermelon seed oil was below the range of $0.87-$ 0.90 recommended for oil requirement for biodiesel production and so may not be fit as ingredient in biofuel production. Saponification value was used in checking the quality of the oil and found to be far greater than 100. It indicated the presence of unsaturated fatty acid characteristics of foaming ability. Foaming is a desired characteristic of good surfactants with applications in preparation of emulsions, soaps, foam and detergents formulation.

Table 2: Chemical constituents of Watermelon Seeds Oil *

\begin{tabular}{|c|c|c|c|c|c|c|}
\hline $\mathrm{S} / \mathrm{N}$ & RT & AI & Compound & $\begin{array}{l}\text { Mol. } \\
\text { formula }\end{array}$ & Structure & $\%$ Area \\
\hline 1 & 14.359 & 1926 & $\begin{array}{l}\text { Methyl } \\
\text { palmitate }\end{array}$ & $\mathrm{C}_{17} \mathrm{H}_{34} \mathrm{O}_{2}$ & MN & 9.32 \\
\hline 2 & 16.104 & 2089 & $\begin{array}{l}\text { Oleic acid, } \\
\text { methyl } \\
\text { ester }\end{array}$ & $\mathrm{C}_{19} \mathrm{H}_{34} \mathrm{O}_{2}$ & & 62.38 \\
\hline 3 & 16.133 & 2084 & $\begin{array}{l}\text { Methyl } \\
\text { eladate }\end{array}$ & $\mathrm{C}_{19} \mathrm{H}_{36} \mathrm{O}_{2}$ & & 8.41 \\
\hline 4 & 16.339 & 2109 & $\begin{array}{l}\text { Methyl } \\
\text { stearate }\end{array}$ & $\mathrm{C}_{19} \mathrm{H}_{38} \mathrm{O}_{2}$ & & 6.24 \\
\hline 5 & 16.671 & 2155 & $\begin{array}{l}\text { Ethyl } \\
\text { linoleate }\end{array}$ & $\mathrm{C}_{20} \mathrm{H}_{36} \mathrm{O}_{2}$ & & 8.83 \\
\hline 6 & 18.697 & 2012 & $\begin{array}{l}\text { Methyl } \\
8,11,14- \\
\text { heptadecatr } \\
\text { ienoate }\end{array}$ & $\mathrm{C}_{18} \mathrm{H}_{30} \mathrm{O}_{2}$ & & 2.17 \\
\hline 7 & 25.529 & 1745 & $\begin{array}{l}\text { I. 5- } \\
\text { Methyl-2- } \\
\text { Phenyl- } \\
\text { Indolizine }\end{array}$ & $\mathrm{C}_{15} \mathrm{H}_{13} \mathrm{~N}$ & & 2.66 \\
\hline
\end{tabular}

*Percentages calculated from the flame ionization detection data. RT $=$ Retention Time; AI = Arithmetric Retention Index on HP-5MS column.

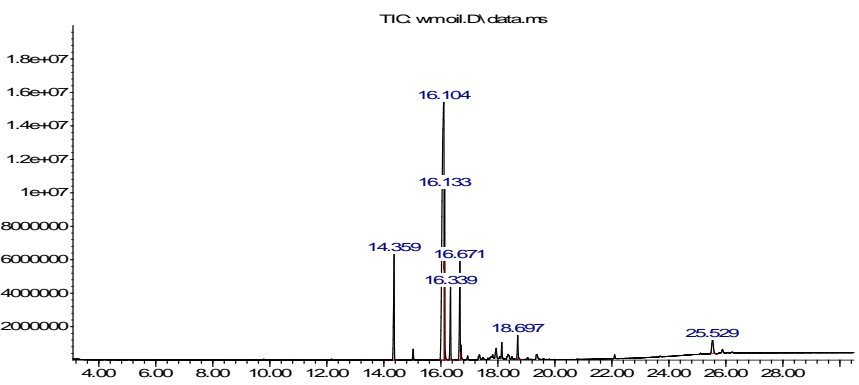

Figure 1: GC Spectrum of Water melon seed oil 
A total of 7 components were detected in the watermelon seed oil, totalling $100 \%$ and dominated by oxygenated terpenes and an indolizine alkaloid (Table 2). The GC spectrum is shown in Figure 1. The watermelon seed oil had a high concentration of unsaturated fatty acids when compared with other similar oil seeds in literature. The main component was oleic acid, methyl ester (62.38\%), methyl palmitate $(9.32 \%)$ and methyl stearate $(6.24 \%)$. Linoleic acid was however the dominant fatty acid $(68.3 \%)$ in the watermelon seed oil from Iran (Baboli and Kordi, 2010). Figure 2 shows the mass spectrum of the most abundant compound, Methyl 9 cis, 11- methyl 9-cis, 11-trans-octadecadienoate (oleic acid, methyl ester) obtained from water melon seed oil from Nigeria. Oleic acid and its derivatives are used as an emollient. Methyl palmitate and methyl stearate are used as food additives and flavouring agents while ethyl linoleate $(8.83 \%)$ detected in the oil is one of the most abundant essential polyunsaturated fatty acids which can be used as a reference material in assays that quantify fatty acid ethyl esters (FAEEs) for detection of alcohol abuse and studied as an acetylcholinesterase (AChE) inhibitor (Vick, 1993). Other compounds are Methyl eladate (8.41\%), Methyl 8,11,14-heptadecatrienoate (2.17\%) and 5-Methyl2-Phenyl-Indolizine (2.66\%).

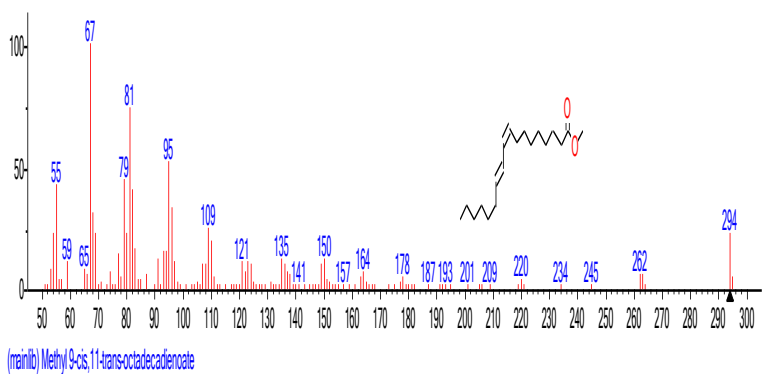

Figure 2: Mass Spectrum of Methyl 9 cis, 11- methyl 9-cis, 11trans-octadecadienoate (Oleic acid, methyl ester) obtained from Water melon seed oil.

Watermelon seeds oil is one of the most undermined seed oil, with the most utilised being the soybean, rapeseed (Brassica napus), cotton (Gossypium hirsutum), peanut (Arachis hypogaea) and sunflower oils in decreasing order. Oil seed plants are plants that have seeds with a high level of oils used as energy reserves and can be used for human food and/or biodiesel production. They also possess reasonably balanced amounts of carbohydrates, fats and proteins (El-Adawy and Taha, 2001; Rodrigues et al., 2012). The seeds of watermelon are increasingly being used in the oil industry in semi-arid regions by cosmetics and pharmaceutical industries and also the prospect of use of the seeds in the improvement of infant formulation due to their high protein and fat content is on the increase (Poysa and Woodrow, 2002; Nwanko et al., 2014). The most abundant compound in this oil, oleic acid methyl ester is a monounsaturated fat in human diet which decreases low density lipoprotein (LDL) cholesterol, decreased risk of breast cancer and hypotensive (Martin-Moreno et al., 1994; Pala et al., 2001; Teres et al., 2008). Thus an important contribution to food resources or industrial products can be made.

\section{Antioxidant Activity of the Essential Oils}

The increase in awareness of the use of watermelon seed oil especially as anticancer agent has necessitated investigation of its biological relevance. Therefore screening of watermelon seed oil for antioxidant activity will justify its use as free radicals are reported to be the major causative agents of many degenerative diseases including cancer. DPPH assay and Reducing Power Methods were used. Results obtained (Table 3) showed that there was reduction in absorbance values in the oil sample after incubation in DPPH as concentration is increased unlike in the reducing power method where there was increase in the absorbance of the reaction as concentration is increased, indicating an increase in the antioxidant activity. At the highest concentration $(1000 \mu \mathrm{g} / \mathrm{mL})$, absorbance values were $0.788 \pm 0.013$ and $0.868 \pm 0.002$ whereas at the lowest concentration $(100 \mu \mathrm{g} / \mathrm{mL})$, absorbance values were $0.892 \pm 0.001$ and $0.487 \pm 0.001$ for the two assays respectively. Ascorbic acid however showed better activity in the DPPH assay with absorbance value of $0.090 \pm 0.001$ at $1000 \mu \mathrm{g} / \mathrm{mL}$ (Table 3). The percentage inhibition as shown in Figure 1 indicated that water melon seed oil displayed moderate activity in the two assays.

Table 3: Absorbance values obtained in the DPPH assay and
Reducing Power Method (RPM) of Water melon seed oil .

\begin{tabular}{llll}
\hline $\begin{array}{l}\text { Conc } \\
(\mu \mathrm{g} / \mathrm{mL})\end{array}$ & DPPH ASSAY & $\begin{array}{l}\text { ASCORBIC } \\
\text { ACID }\end{array}$ & RPM \\
\hline 1000 & $0.788 \pm 0.013$ & $0.090 \pm 0.001$ & $0.868 \pm 0.002$ \\
800 & $0.799 \pm 0.020$ & $0.092 \pm 0.004$ & $0.629 \pm 0.011$ \\
600 & $0.825 \pm 0.011$ & $0.093 \pm 0.000$ & $0.620 \pm 0.001$ \\
400 & $0.835 \pm 0.015$ & $0.093 \pm 0.005$ & $0.577 \pm 0.004$ \\
200 & $0.836 \pm 0.014$ & $0.094 \pm 0.001$ & $0.562 \pm 0.007$ \\
100 & $0.892 \pm 0.001$ & $0.095 \pm 0.005$ & $0.487 \pm 0.001$ \\
& & &
\end{tabular}

*Absorbance measurement of Water melon seed oil and standard: ascorbic.

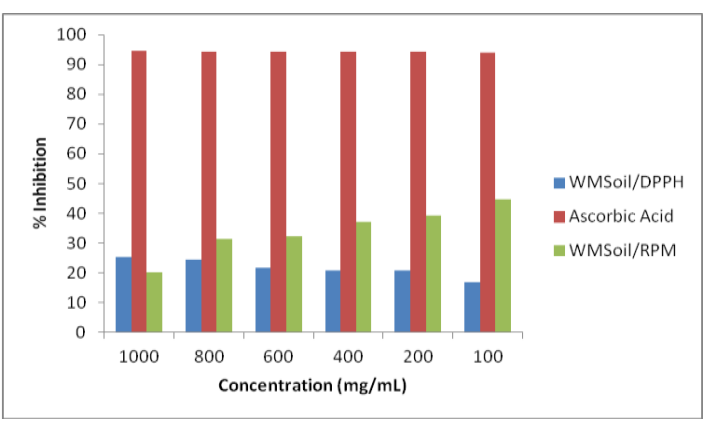

Figure 1: Percentage Inhibition of DPPH free radical scavenging activities and Reducing Power of Water melon seed (WMS) oil and Ascorbic. 


\section{CONCLUSION}

Watermelon seed oil contains mainly esters of fatty acids dominated by methyl 9-cis, 11-trans-octadecadienoate (Oleic acid methyl ester). The free radical scavenging activity in terms of hydrogen donating ability, using the stable radical 2,2-diphenyl picrylhydrazyl radical (DPPH) and reducing power methods indicated that Watermelon seed oil showed moderate activity. The high oil content of watermelon seed coupled with fairly high concentration of fatty acid make the seed suitable as food supplement. It may also enjoy applications as industrial ingredients in soap production, cosmetics, and foam ingredient. The by-products emanating from the processing could be useful in firing boilers for plants or as animal feed if properly processed.

\section{Acknowledgment}

The authors appreciate the staff of Central Science Laboratory, University of Lagos for the use of GC/GC-MS equipment and Aderibigbe S.A. appreciate the Department of Pharmaceutical Chemistry, University of Ibadan for the use of UVVisible Spectrophotometer used for the antioxidant screening.

\section{References}

[1] R. P., Adams.. Identification of Essential Oil Components by Gas Chromatography/Mass Spectrometry. 4th ed. Allured Publishing Corporation, Carol Stream IL, USA. 2007.

[2] S., Teres, G., Barcelo-Coblijn, M. Benet, R., Alvarez, R., Bressani, J. E., Halver, P. V. Escriba,. "Oleic acid content is responsible for the reduction in blood pressure induced by olive oil". Proceedings of the Nat Acad Sci. 2008, vol. 105 No 37, pp 1381113816 doi:10.1073/pnas.0807500105

[3] V., Pala, V, Krogh,. P., Muti, V. Chajes, E, Riboli, A., Micheli, M., Saadatian; S., Sieri,; F., Berrino. "Erythrocyte Membrane Fatty Acids and Subsequent Breast Cancer: A Prospective Italian Study". JNCI J Nat Cancer Inst. 2001, vol. 93 No 14, pp 10881095. doi:10.1093/jnci/93.14.1088.

[4] J.M., Martin-Moreno, W.C, Willett, L, Gorgojo, J.R, Banegas Rodriguez-Artalejo F, Fernandez-Rodriguez JC, Maisonneuve P, P., Boyle.. "Dietary fat, olive oil intake and breast cancer risk". Internat $\mathrm{J}$ of Cancer. 1994, vol 58 No 6, pp 774780. doi:10.1002/ijc.2910580604

[5] J. Aranceta. Fruits and Vegetables. Archivos Latinoamericanos de Nutricion, 2004, No 54, No 1 pp 65-71

[6] Z.M , Baboli. and A.S.,. Kordi. Characteristics and Composition of Watermelon Seed Oil and Solvent Extraction Parameters Effects. J Am Oil Chem Soc. 2010, vol 87 No 6, pp 667-671.

[7] A.A., Boligon, M.M., Machadom, and M.L. Athayde,. Technical Evaluation of Antioxidant Activity, Medic Chem 2014 vol 4, No7, pp 517-522.

[8] C., Chitravadivu, S.Manian and K. Kalaichelvi,. Qualitative Analysis of Selected Medicinal Plants. Tamilnadu, India MiddleEast J Sci Res, 2009, vol 4, No 3, pp 144-146.

[9] S., David, P., Zelda and G.K. Fulton,. Gas Chromatography and Mass Spectrometry: A Practical Guide. Academic Press. ISBN 978-0-08-092015-3. 2011.

[10] G.D., Diomande,. A. M., Koffi, and Z.F. Tonzibo.. GC and GC/MS analysis of essential oil of five Afranomium species from Cote D ivoire, Middle East Sci Res 2012 vol 11, No 6, pp 808-813.

[11] B.B. Desai and D.K., Salunkhe Fruits and Vegetables. Foods of Plant Origin, J Pharmacog Phytochem 1991, vol 8,pp 301-412.

[12] Duduyemi, O., Adebanjo, S.A., and Oluoti, K.. Extraction and determination of physico-chemical properties of watermelon seed oil. Inter J Sci Technol Res, vol 2, No 8, pp 2277-8616.
[14] Ensminger, A.H. and Ensminger, M.K. (1986). Food for Health: A Nutrition Encyclopedia Choris California Pegus press: pp 10611072.

[15] Erhirhie, E.O., and Ekene, N.E. (2013). Medical values on Citrullus lanatus. Inter J Res Pharmaceu Biomedic Sci vol 4, No 4, pp 1305-1311.

[16] Gohlke, R., McLafferty, and Fred W. (1993). "Early gas chromatography/mass spectrometry". J Amer Soc for Mass Spectrom 4 (5): 367. http://dx.doi:10.1016/1044-0305(93)85001-E

[17] Gul S, Rashid Z. and Sarwer G. (2014). Citrullus lanatus (watermelon) as Diuretic agent: An in vivo investigation on mice. Amer J Drug Delivery Therapeut; vol 1, No 4, pp 089-092.

[18] Halliwell B, Murcia M.A, Chirico S. and Aruoma, O.I (1995). Free radicals and antioxidants in food and in vivo: what they do and how they work. Critical Review Food Science Nutrient 35: 7-20 Kokate, C.K., (1993). Practical pharmacognosy. Vallabhprakashan, Delhi India, pp: 107- 111.

[20] Lawrence, B.M., (1985). A review of the world production of essential oils. Perfumer Flavorist, vol 10, No 5, pp 1-12.

[21] Leland, J.C., Ara, K., Peter, B.K., Sara, W., James, A.D. and Harry L.B. (2006). Natural Products from Plants. (2nd ed.). Boca Raton: CRC Press Taylor \& Francis Group.

[22] Mclafferty, F. W and Stauffer, D.B. (1989). The Willey/NBS Registry of Mass Spectral Data. John Willey and Sons, New York.

[23] Marriott, P. J.; Shelliea, R.; and Cornwell, C. (2001). Gas chromatographic technologies for the analysis of essential oils. J Chromatogr pp A 936 1-22 3.

[24] Munisse, P., Andersen, S.B., Sensen, B.D. and Christiansen J.L. (2011). Diversity of landraces, agricultural practices and traditional uses of watermelon (Citrillus lanatus) in Mozambique. Afr J Plant Sci, vol 5, No 2, pp. 75 -86.

[25] NurAlam, M.D., Nusrat J.B. and Rafiquzzaman, M.D., (2013). In vivo and in vitro methods evaluation of antioxidant activity. Saudi Pharmaceut J, vol 21:pp 143-152.

[26] Nwanko, I.U., Onwuakor, C.E. and Nwosu, V.C., (2014). Phytochemical analysis and antibacterial activities of Citrullus lanatus seeds against some pathogenic micro-organisms. Global J Med Research: C Microbiol Pathol vol 14, pp 20 - 26.

[27] Onocha, P.A., Oloyede, G.K. and Afolabi, Q.O. (2011) Chemical Composition, Cytotoxicity and Anti-oxidant Activity of Essential Oils of Acalypha hispida Flowers. Inter.J Pharmacol vol 7: pp 144-148.

[28] Oloyede G. K. and Egbewole I. S. (2014). Chemical constituents and antimicrobial activity of essential oil of Combretum hispidum leaves AU J Technol 18 (2): 69-74.

[29] Oyedeji, F.O. and Oderinde, R.A. (2006). Characterization of isopropanol extracted vegetable oil. J Applied Sci. 6, 2510-2513. Retrieved from http://dx.doi.org/10.3923/jas.2006.2510.2513

[30] Pari, L. and Umamaheswari, J. (2000). Antihyperglycaemic activity of Musa sapientum flowers: effect on lipid peroxidation in alloxan diabetic rats. Phytother. Res., 14: 1-3.

[31] Parry, J., Su, L., Luther, M., Zhou, K., Yurawecz, M.P., Whittaker, P. and $\mathrm{Yu}, \mathrm{L}$. (2005). Fatty acid composition and antioxidant properties of cold-pressed marionberry, boysenberry, red raspberry, and blueberry seed oils. J Agric Food Chem. vol 53, pp 566-573. Retrieved from http://dx.doi.org/10.1021/jf048615t

[32] Pritchard, J. and Rossell, J.B, (1991). Analysis and properties of oil seeds: Analysis of oilseeds, fats and fatty foods. Elsevier Applied Sci, New York, pp 39-102.

[33] Rahman, H., Manjula, K., Anoosha, T., Nagaveni, K., Eswaraiah, M.C. and Dipankar, B. (2013) In vitro anti-oxidant activity of Citrullus lanatus seed extracts. Asian J Pharmaceu Clinic Res, 2013, vol 6, No 3, pp 152-157.

[34] I.M., Rodrigues, J.F.J. Coelho, and M.G.V.S., Carvalho,. Isolation and valorisation of vegetable proteins from oilseed plants: Methods, limitation and potential. J Food Engineer 2012, vol 109, pp 337 - 346. 
Proc. of the Sixth Intl. Conf. Advances in Bio-Informatics, Bio-Technology and Environmental Engineering- ABBE 2018 Copyright (C) Institute of Research Engineers and Doctors, USA. All rights reserved.

ISBN: 978-1-63248-148-1 doi: 10.15224/978-1-63248-148-1-08

[35] J.B. Rossell,. Vegetable oil and fats. In Analysis of Oilseeds, Fats and Fatty Foods; Elsevier Applied Science: New York, 1991 pp 261-328.

[36] J, Sun, Y.F., Chu, X.,. Wu, and R.H. Liu,: Antioxidant and antiproliferative activities of common fruits. J Agric Food Chem, 2002, vol 50, No 25, pp 7449-7454.

[37] A.A., Taiwo, M.O., Agbotoba, J.A., Oyedepo, O.A., Shobo, I. Oluwadare and M.O., Olawunmi,. Effects of drying methods on properties of water melon (Citrullus lanatus) seed oil. Africa. J Food Agric Nutr Dev. 2008, vol 8, pp 1684-5374.

[38] M. P., Tarazona-Díaz, F., Alacid, M., Carrasco, I. Martínez, and E. Aguayo,. Watermelon juice: potential functional drink for sore muscle relief in athletes. J Agric Food Chem, 2013 vol. 61 No 31, pp 7522 7528. Retrieved from http://pubs.acs.org/doi/abs/10.1021/ jf400964r

[39] R.M, Tilak, A., Tukaram, M.L. Brij, and S.S. Valangaman, A study of seeds of musk melon (Cucumismelo L.), a lesser known source of edible oil. J Sci Food Agric. 2006, vol. 10, pp 973-978.

[40] B.A. Vick. Oxygenated fatty acids of the lipoxygenase pathway. Lipid Metab I Plants 1993, pp 167-191.

[41] A.K. Ziyada, and S.A. Elhussien,. Physical and chemical characteristics of Citrullus lanatus and Various Colocynthoide seed oil. J Phys Sci 2008, vol. 19, pp 69-75.

About Author (s):

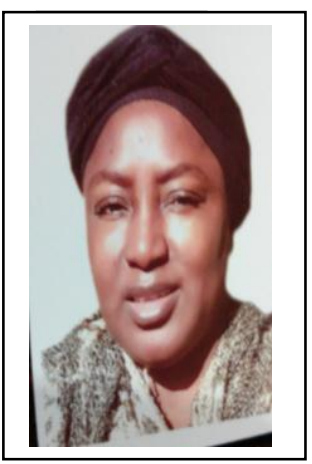

Dr Ganivat K. Oloyede Is a Senior Lecture at the University of Ibadan, Nigeria

Current Research Interest

Chemistry of Natural Products and their Medicinal Uses.

Phytochemical evaluation of Medicinal Plants with emphasies on antioxidant, anticancer and hepatotoxic activities.

Isolation and Characterisation of bioactive chemical compounds from plants Synthesis of Schiff and Mannich Bases and invesitigation of their biology activities.

About Author (s):

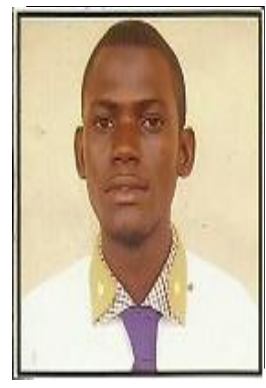

Mr Sodeeg A. Aderibigbe Is a Research Student at National Open University of Ibadan, Nigeria.

Current Research Interest

Chemistry of Natural Products and their Medicinal Uses.

Phytochemical evaluation of Medicinal Plants with emphasies on antioxidant, activities.

activities. 